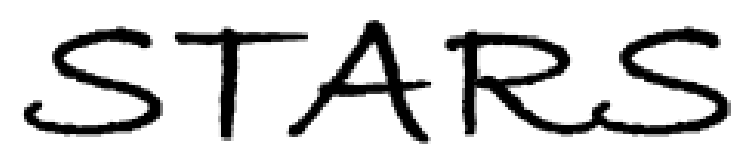

Rosen Research Review

Volume 2

Issue 2 Summer 2021

Article 10

July 2021

\title{
Households' Net Financial Wealth as a Determinant of Tourism Demand Cycles: Evidence from US Travel to Selected Caribbean Destinations
}

Jorge Ridderstaat

University of Central Florida, Jorge.Ridderstaat@ucf.edu

Part of the Tourism and Travel Commons

Find similar works at: https://stars.library.ucf.edu/rosen-research-review

University of Central Florida Libraries http://library.ucf.edu

This Article is brought to you for free and open access by the Rosen College of Hospitality Management at STARS. It has been accepted for inclusion in Rosen Research Review by an authorized editor of STARS. For more information, please contact STARS@ucf.edu.

\section{Recommended Citation}

Ridderstaat, Jorge (2021) "Households' Net Financial Wealth as a Determinant of Tourism Demand

Cycles: Evidence from US Travel to Selected Caribbean Destinations," Rosen Research Review. Vol. 2 : Iss. 2 , Article 10.

Available at: https://stars.library.ucf.edu/rosen-research-review/vol2/iss2/10

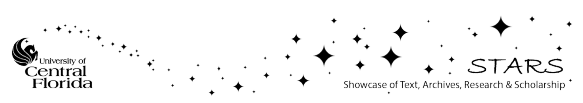




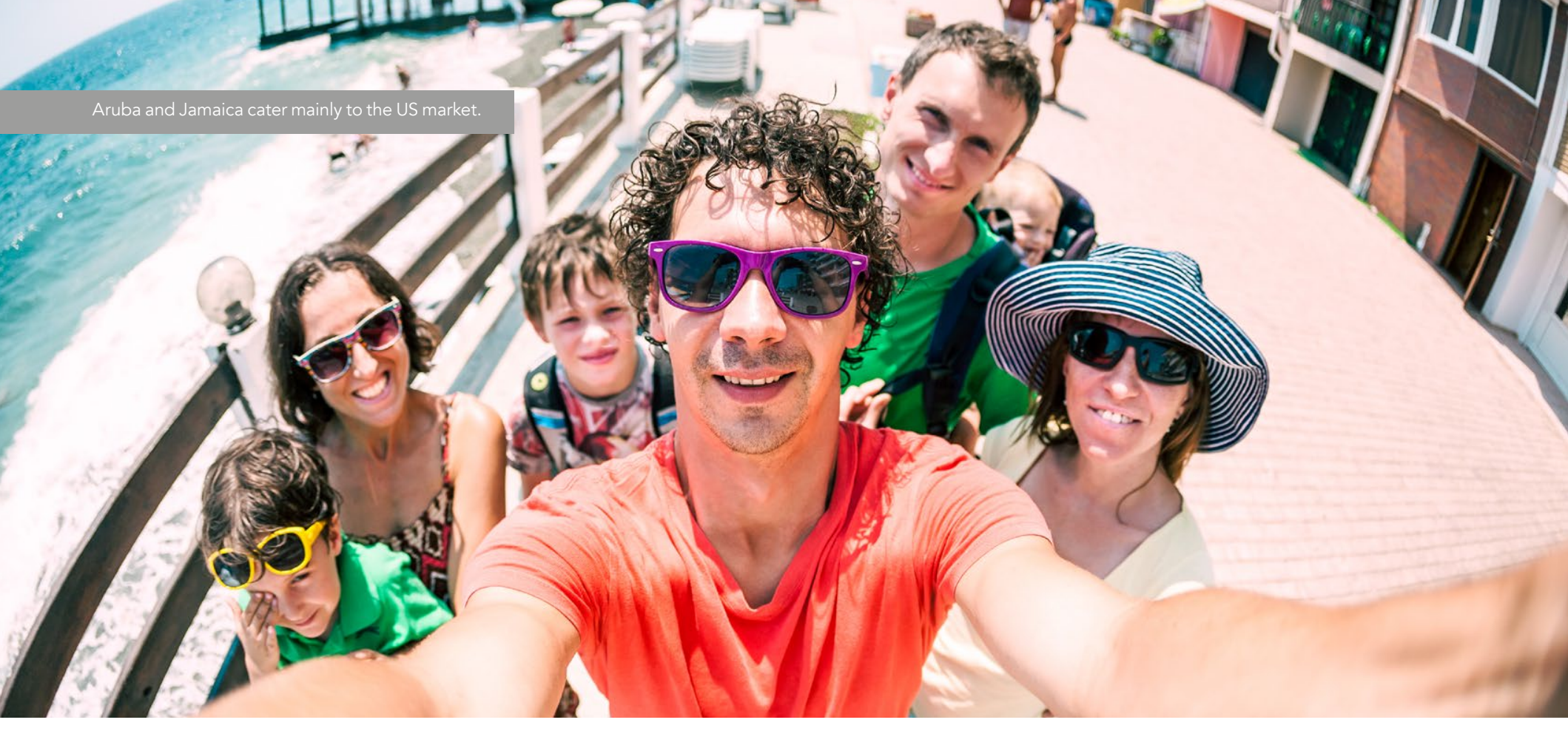
collected using the Surveys of Consumers to the US market, while Barbados has thr large markets: the UK, US, and Canada.

\section{DATA COLLECTION}

Monthly observations were collected for the 23 years from January 1996-December conducted by the University of Michigan. The survey sample represented all Americ households, excluding Alaska and Hawaii. Tourism demand data for the three islands

run cycle equilibrium relationship between tourism demand and those of the nine regression to measure the rediombip between variables and determine whether the households' financial position cycles affect tourism demand cycles. Finally, he applied a logistic regression approach form of regression with a binary dependent variable-to the tourism demand cycles with the expansion phases coded as one and the contraction phases coded as zero. Using this

THE GOAL SHOULD BE TO PROLONG EXPANSION PERIODS OF TOURISM DEMAND, THUS SHORTENING THE CONTRACTION PERIODS by their central banks.

\section{ANALYSIS}

Dr. Ridderstaat used the unobserved

components model (UCM) to decompose

the time series into trend, seasonal, cyclical

the resulting cycles and complat

statistical method called a unit root test

avoid spurious or regression results.

Then he tested for co-integration to

D. Ridders at found that the rests differed between periods of expansion and contraction in tourism demand cycles. Furthermore, on Five of the nine households could nine households could become tourists in the came from the socioeconomic data collected

\section{RESEARCHERS}

I N FOCUS

\section{RESEARCH OBJECTIVES}

Dr. Jorge Ridderstaat assesses net financial wealth as a determinant of tourism demand.

\section{REFERENCES}

Ridderstaat J. (2021). Households' Net Financial Wealth as a Determinant of Tourism Demand Cycles: Evidence from US Travel to Selected Caribbean Destinations. Journal of Travel Research. [onlin
org/10.1177/0047287520925174

\section{PERSONAL RESPONSE}

Why do you think that net financial wealth has not been considered as an indicator of tourism demand prior to your research? contraction stage. Interestingly, neither Allied
nor Waned Capstoners affected the expansion of the destintions. The may pror other destinations, or wealth effects may not alter their tourism consumption. The results are also country-specific, which may well reflect the unique characteristics of the islands.

Dr. Ridderstaat notes that these contextual conditions echo the heterogeneity in consumers' decisions, indicating that a onesize-fits-all approach to understanding the effect of wealth position perceptions on US tourism demand cycles may not be possible for these destinations. A circumstantial approach may be required instead.

IMPLICATIONS

Dr. Ridderstaat's research reveals that the influence of net financial wealth on tourism demand is context-based and specific to households, cycles, and countries, across both time and probability dimensions. Context matters for policymaking. The goal should be to prolong expansion periods policymakers US tourism demand for their destination by targeting households based on their probabilities and reaction periods. Destinations should therefore, follow a diagnostic approach based on what works for them rather than automatically pursuing best practice approaches such as targeting

III think it has to do with two factors: (1) lack of knowledge that this indicator exists, and (2) researchers are not critical enough and often follow the standard way of using income as an indicator. Researchers may not always be aware that such an indicator exists, and to give edit, it may also be possible that such an indicator may likely not 列 choose the road of least resistance by just using conventional methods. contraction periods He roconing the

Previously, Dr. Ridderstaat worked for some 20 years at the Central Bank of Aruba (CBA) first as an economist at the Economic Policy Manager of the Researth Depasthent in the Manager of the Research Department. In the
latter function, he directed and guided the Research Department with the mission to support the policies of the CBA.

\section{E: Jorge.Ridderstaat@ucf.edu}

W: https://hospitality.ucf.edu/person/jorge dderstaat tourism demand cycle for the destintions.

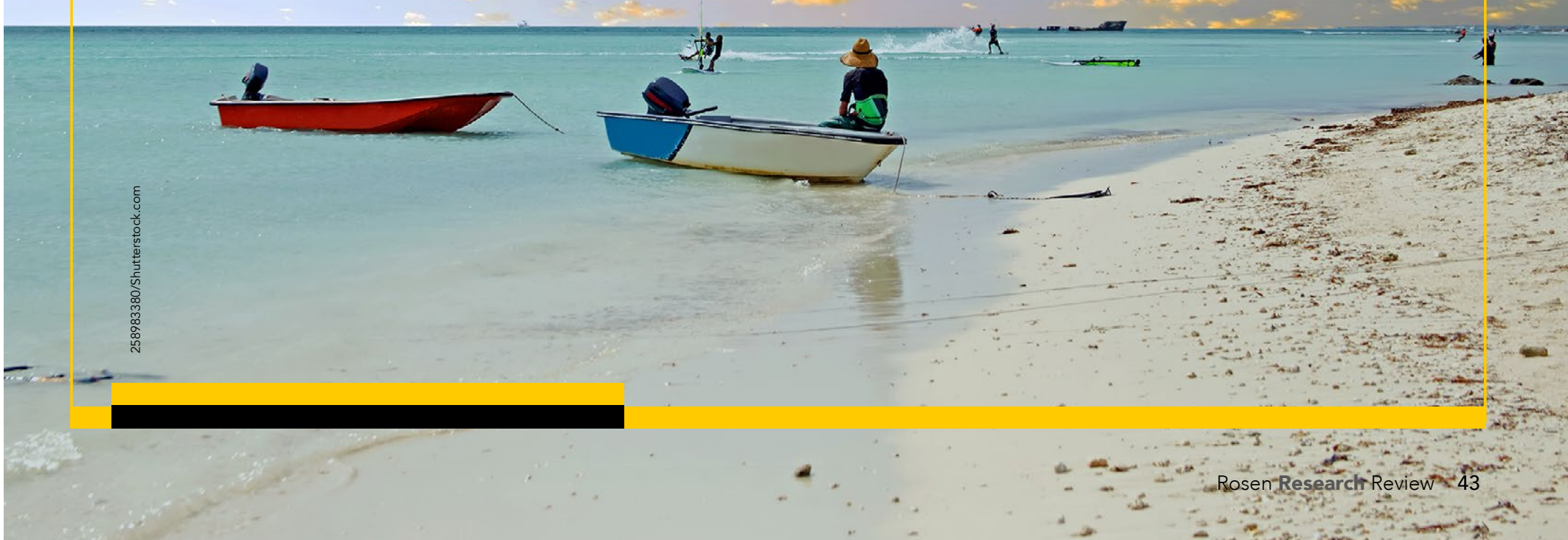

